\title{
MAPPING OF THE LOWER COURSE OF BARRA GRANDE RIVER, DOIS RIOS CREEK, ILHA GRANDE, BRAZIL, BASED ON DATA OF SIDE SCAN SONAR
}

\author{
Helio Heringer Villena ${ }^{1 *}$, Verônica Beatriz Araujo De Castro $^{1}$ and Patricia Da Cunha Marroig ${ }^{2}$
}

1 Faculdade de Oceanografia, Universidade do Estado do Rio de Janeiro, UERJ, Rua São Francisco Xavier, 524, 4ªndar, Bloco E, sala 4018, CEP 20550-900, Rio de Janeiro, RJ, Brazil. heliovillena@gmail.com, vevel.castro@gmail.com

2 Programa de Pós-graduação em Engenharia Oceânica/Pesquisadora colaboradora no Laboratório de Dinâmica de Sedimentos Coesivos - COPPE/UFRJ, Centro de Tecnologia, Bl. I-100, CEP 21941-590, Cidade Universitária, Rio de Janeiro, RJ, Brazil. pmarroig@oceanica.ufrj.br

*CORRESPONDING AUTHOR, heliovillena@gmail.com

Received on 18 September 2017

Received in revised form on 27 October 2017

Accepted on 28 October 2017

Editor: Maria Antonieta da Conceição Rodrigues, Universidade do Estado do Rio de Janeiro, Brazil

\section{Abstract}

The present work uses a modern generation of side scan sonar aiming to obtain sonographic images of the coastal region of Barra Grande River, located in the Dois Rios Creek, Ilha Grande, SE Brazil. This technological advanced technique has enabled to obtain sonographic imaging of ultra-shallow areas, at depths between 1 and 5 meters in the study area. From the obtained records and the sonographic patterns, seven areas / features closely related to characteristic sites and / or processes observed in the low fluvial course were identified. This mapping allowed to

\section{Introduction}

Since the antiquity man seeks to acquire knowledge of the rivers, lakes, lagoons, estuaries, bays and oceans submerged areas. This search can vary in its purpose from a simple curiosity either for fishing, safety to navigation, mineral exploration, pure or applied research proposes and, more recently, for protection and environmental preservation activities.

Underwater researches are hampered by human inability to perform autonomous dives, either by normal apnea, by normal aqualung diving or gas mixed aqualung dive. The greatest depth reached by man in autonomous diving, using

\section{SCREENED BY}

$\checkmark$ iThenticate

Citation:

Villena, H.H., Araujo de Castro, V.B., Marroig, P.C., 2017. Mapping of the lower course of Barra Grande River, Dois Rios Creek, Ilha Grande, Brazil, based on data of side scan sonar. Journal of Sedimentary Environments, 2 (3): 182-194.

correlate the features observed in geological, geomorphological, hydrological and sedimentological studies in Ilha Grande, making possible the analysis of the final portion of the Barra Grande River course, in the coastal plain of the Dois Rios Creek, on this island.

Keywords: Zonography. Side-Scan Sonar. Sonographic Mapping. Sediments.

all existing technology, reached $332.35 \mathrm{~m}$ (Janela, 2014). The strategy adopted to overcome these limitations was the use of indirect (optical, acoustic, electrical, potential, etc.) or direct methods (recovering samples and cores).

Direct samplings are punctual and of restricted representativeness, a fact that would imply the necessity of numerous sampling events for detailed studies, making research much more expensive. To get an overview of marine systems sedimentary environments, the ideal solution is to apply indirect methods. 
Optical methods are compromised by the rapid attenuation of electromagnetic waves in the marine environment due to absorption and scattering (Lurton, 2002). The euphotic zone, where there is light penetration into the oceans, can reach about $200 \mathrm{~m}$ in the limpid open ocean (Kaiser et al., 2011). In the coastal zone and continental shelf boundaries the light penetration can be drastically reduced by increasing the amount of suspended matter, including sediments, pollutants or biota.

The potential methods, magnetometry and gravimetry, are used in numerous approaches and geological models being of great value for regional and geological structuring studies. The limitations found in these methods are related to the difficulty of the sources individualization, in gravimetry, and due to the erratic character and strong local influence on magnetometry (Telford et al., 1990 a, b).

Acoustic methods, in turn, are extremely effective due to the great distances in which the sound, a mechanical wave, propagates in the water, being able to fully reach the seafloor, since appropriate frequencies are used. This is due to the higher sound attenuation as a function of the frequency of the wave, since the higher frequency will generate greater attenuation and the lower frequency will give place to less attenuation and greater range penetration.

The development of submarine acoustics was first carried out for military purposes (Lurton, 2002) in the two great world wars and later for scientific and commercial purposes for underwater explorations for proposals of oil exploration in sedimentary basins located in the continental margins of producing countries. This resulted in single-beam echo sounders, seismic profilers, side-scan sonar, multi-beam echo sounder, sonar imagers, acoustic positioners, acoustics modems, etc.

\subsection{The main goals}

This work aims to obtain sonographic imaging of ultrashallow areas, at depths between 1 and 10 meters, at the coastal portion of the Barra Grande River, located in Dois Rios Creek, Ilha Grande, (SE Brazil) in order to recognize sonographic patterns and structures / targets and to give support to the description of geomorphological domains of the island.

\section{Study area}

The coast of Rio de Janeiro State is located in the Southeast Region of Brazil and has three large bays: Guanabara, Sepetiba and Ilha Grande. Of these, Ilha Grande Bay is the one that has the best environmental preservation, being this condition associated with its distance from the metropolitan region of Rio de Janeiro. Its river drainage is completely separated from the highly anthropized hydrographic basins of Sepetiba and Guanabara bays, which are highly influenced by industrial poles and the metropolitan region of Rio de Janeiro.

The Ilha Grande Bay has a more open communication with the Atlantic Ocean than the other two bays and, lastly, it has greatest areas of environmental preservation, including the continental coast and aquatic body zones.

The Dois Rios Creek, where the Barra Grande River is located, is on the oceanic side of Ilha Grande, in its southeast portion, with its mouth facing southeast region too (Fig. 1). This cove has approximately $1.5 \mathrm{Km}$ long and $1.3 \mathrm{Km}$ wide. It receives two fluvial contributions, the Barra Grande River, object of this study, at the south end of the beach and the Barra Pequena River at the north end of the beach.

The origin of the rocks of the crystalline basement of the Ilha Grande occurred between 630 and 480 million years ago when the collision of paleocontinents generated an extensive mountain range currently named Faixa Ribeira (Gama et al., 2009). According to Heilbron et al. (2004), this strip of crystalline terrain, with NE-SW preferential structure direction, is composed of stacked plaques formed during the collision stages of Brasilian Orogenenesis. However, the igneous rocks, located on the large island, escape to this pattern because they are post-collisional intrusions (Valeriano et al., 2016).

Gama et al. (2009) considered five lithological units in Ilha Grande (Fig. 2) which are described below:

- Orthogneiss of the Rio Negro Complex - the oldest rocks of the island, being observed in outcrops located in the Laje do Demo (coast between the Praia do Sul and Praia do Aventureiro, two beaches); west part of the Araçatiba cove; and at the Bananal tip, at south of the Ilha dos Macacos.

- Ilha Grande charnockite suite - occurs in east and west extensive portions of the island and is composed by massive and crystalline granite-like rocks, formed in conditions of high temperatures in the earth's crust.

- Vila de Dois Rios Granite - appears in the central area of the island, cutting the charnockite suite and the orthogneiss of the Rio Negro Complex. The highest points of the island are formed by these granites, which are newer intrusive rocks.

- Diabase Dikes - intrusive tabular igneous bodies similar in composition to the ocean floor, related to the opening of South Atlantic Ocean, being observed in Palmas, Dois Rios, Aventureiro, Araçatiba and Ponta do Saco da Freguesia. 


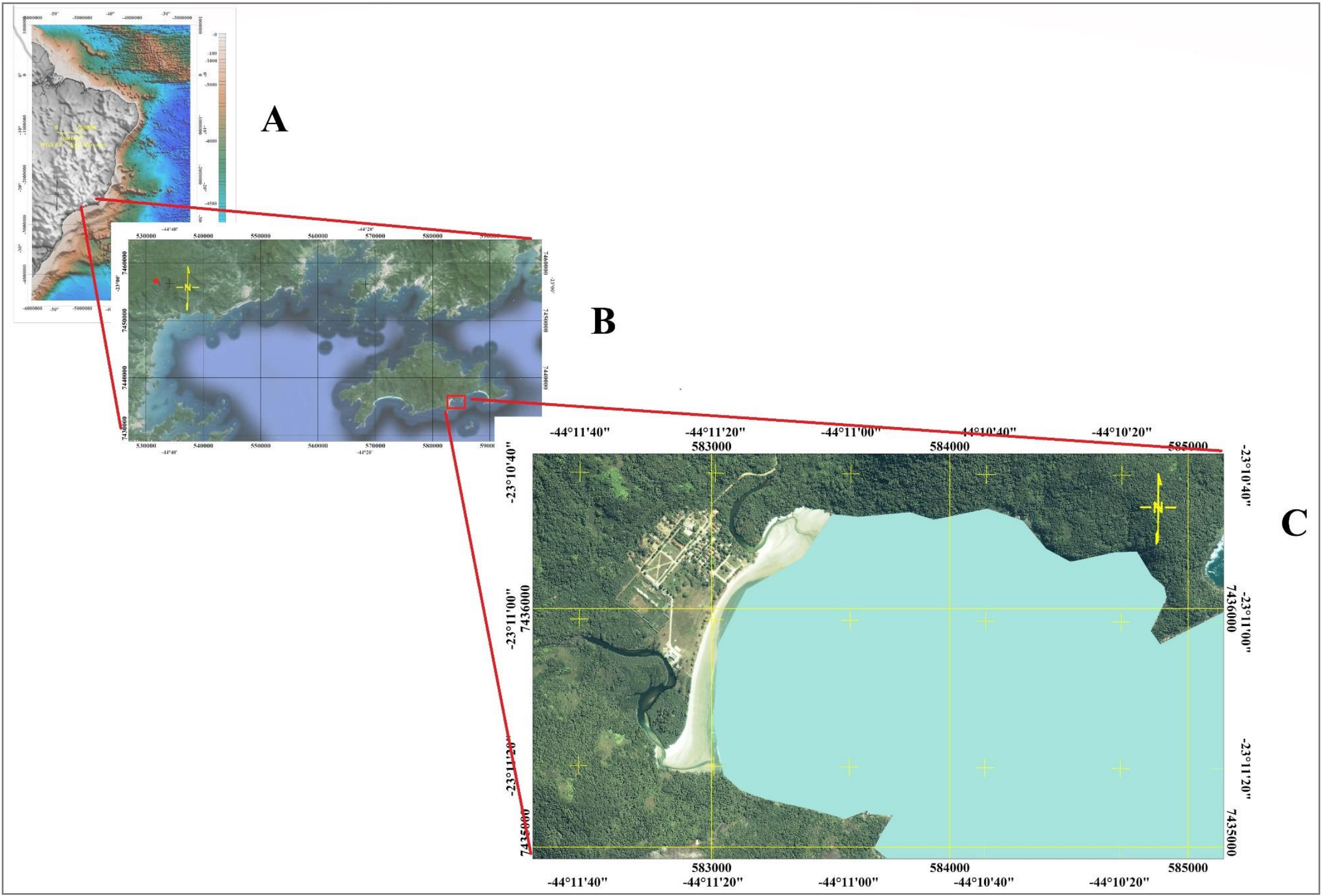

Fig. 1. Location of the study area. A) Map of Brazil indicating the location of Ilha Grande Bay (adapted from Torres et al., 2010); B) Map of Ilha Grande with the location of Dois Rios Creek (Adapted from Google Earth Image, 2016); and C) Map of the lower course of the Barra Grande River (UTM 23S). 


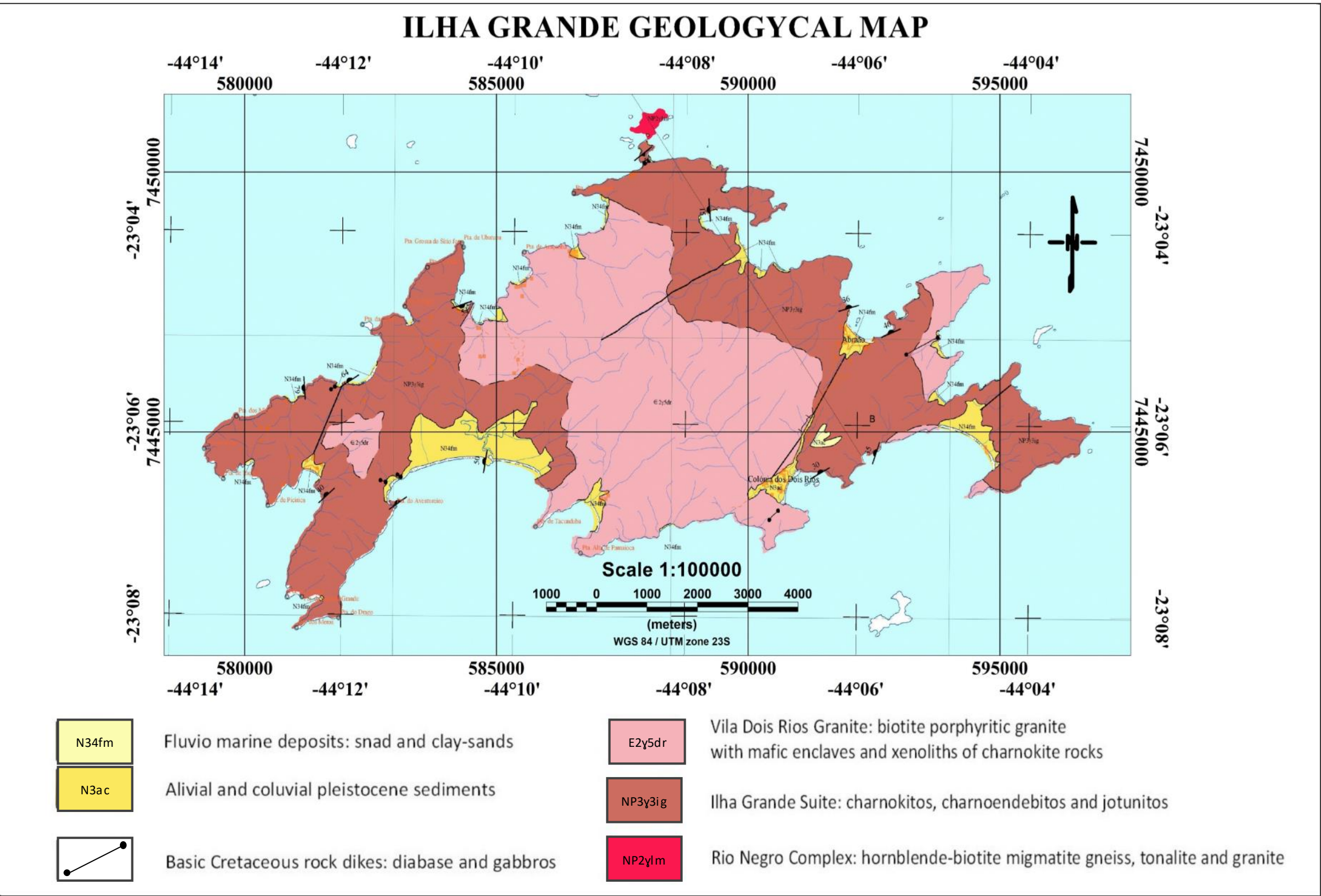

Fig. 2. Geological map of Ilha Grande showing the main observed lithological units (adapted from CPRM, 2007). 
- Sedimentary Deposits - corresponding to the most recent geological record of the island with ages inferior to 40,000 years. They are accumulated at the bottom of the valleys, on slopes and coastal plains of the island and are related to fluvial, slope, lacustrine, marine environments, and to river transport processes. They are also associated with wave energy and tidal currents, besides the wind transport in areas of beaches, where they generate dunes.

The sea-level oscillations since the Pleistocene are fundamental for understanding the Ilha Grande in its most recent context. Mahiques et al. (1989) highlights three significant events, the maximum transgressive (120,000 years before present, or $\mathrm{BP}), 8$ meters above the current; maximum regressive (18,000 years $\mathrm{BP}), 130$ meters below current; and last maximum transgressive (5,100 years BP), 5 meters above the current one. In terms of geomorphology (Fig. 3), Gama et al. (2009) described three geomorphological domains:

- Slope Domain. The emersion relief of the island presents two divisors of waters, one east / west and another north / south, separating the island in four slopes (northwest, northeast, southwest and southeast) that form the geomorphological domain of the same name. The main features are steep slopes, abundant rocky outcrops (peaks, cliffs and rocky coastlines), talus deposits and colluviums resulting from erosion of the slopes, rectilinear river channels in enclosed valleys. Mass movements are common, having the gullies smaller extension.

- Small plateau of the Serra do Papagaio (a mountain), located in the center-east of the island, is characterized by a flattened area in the Serra do Papagaio between the northeast and southeast slopes. It seems to be what remains of a larger feature that has been reduced by river erosion and retreat from the cliffs.

- Domain of sedimentary deposits - related to processes of sedimentary aggradation; it is divided into three environments: sandy beaches, coastal plains and ramps/alluvial - colluvial. The beaches, of varying dimensions, border the island and the most extensive are located on the oceanic face of the island. The coastal plain is a transitional environment influenced by both continental and marine processes. They can be divided into two environments: distal, located near the foothills of the slopes, where river dynamic dominates and sandy river deposits to seashores with clay intercalations and mass movement materials by erosion of the slopes (talus and colluvium with the presence of boulders and blocks) can be present; proximal, near the coast, where marine dynamics is more relevant. The proximal environment presents sandy deposits due to the predominance of the waves, generating sandy beaches, many of them with heavy minerals originated by the decomposition of the rocks of the crystalline basement, except when the tidal action prevails the muddy deposition and the mangrove establishment. Ramps or alluvial / colluvial fans are deposits related to mass movements on the slopes, being composed of colluvium and talus that accumulate at the foot slopes and valleys. The reworking by the surface runoff by the rains or the rivers can leave only the sedimentary portion thicker, generating river bottom courses with gravel and blocks and bumps.

The geological context explains the diversity of relief forms observed in the island due to the interaction between the geological substrate (rocks and structures) and mainly water, the main agent of erosion and transport in humid tropical climates such as that observed on the island. The observed relief features, mainly the fluvial channels, the slopes and the coastline, are also intensely conditioned by the geological substrate.

Granite of Vila de Dois Rios, with high erosive resistance, supports the highest areas in the central part of the island, including the Pico do Papagaio and Pico da Pedra D'água, the altimetric exponents of the island. The coastline, alignment of the coves and the river drainage are conditioned by the faults structure and fractures orientation. The NW orientation of Dois Rios Creek is due to the control of fractures in the crystalline basement.

According to SEMADS (2001), in terms of hydrographic basins, a large number of rivers and streams with significant differences of slope between the upper and lower course, waterfalls that have their springs well preserved by the Atlantic Forest, are observed in Ilha Grande Bay and, consequently, in the island of the same name. Oliveira et al. (2014) identified three river styles in the basin of the Barra Grande River:

- Forested - with large forest cover on the banks, prevailing in the springs, upper and medium river courses, having confined valleys and predominantly rectilinear, with high flow velocity due to slope, but small water volume;

- Rocky Channels - the valley is confined and the river is practically rectilinear, making the connection between the upper portion (forested channel);

- Lower Meanders Channels - partially confined valley with a large number of curves in the river bed and sandy to muddy sediments. Represents the final section of the watercourse, located in the coastal plain until to meet the ocean, the flow of water has lower velocity than in the previous ones, thus, allowing the occurrence of depositional processes of sediments and giving place to the presence of sandbanks, sandbars and, locally, mangroves. 
RESEARCH PAPER

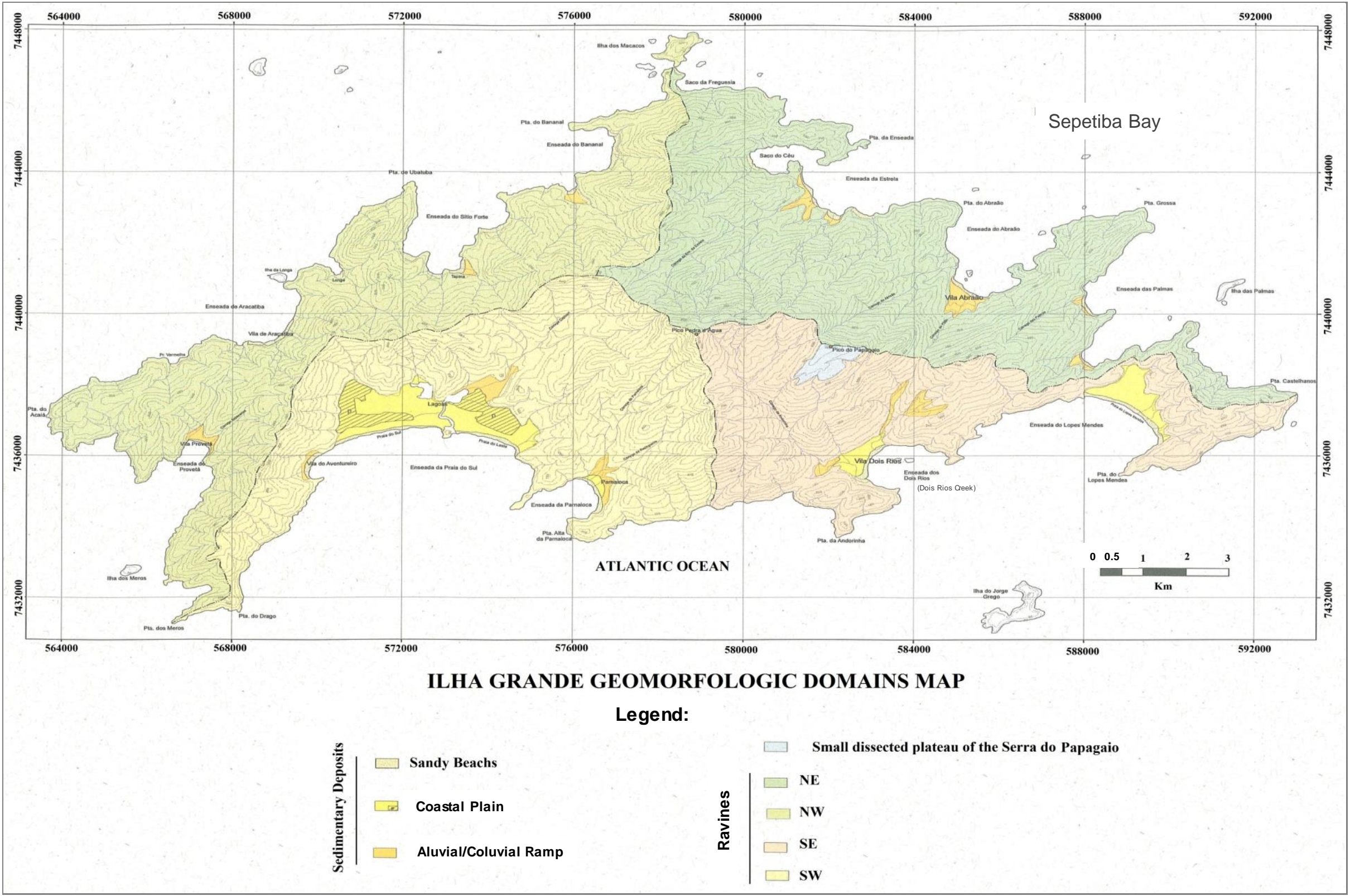

Fig. 3. Map of the Ilha Grande showing the geomorphological domains (adapted from Gama et al., 2009). 
According to Fortes and Pereira (2009), the Barra Grande River basin is the second largest in the island in terms of drainage area $\left(15.24 \mathrm{Km}^{2}\right)$. The section corresponding to the low course of the river, the sonar mapping area presented in this work, is located in the coastal plain of the cove. It has approximately 785 meters in length, going from the area of boulders at the end of the stretch of waterfall of the river to the back of the beach sandbar.

\section{Material and methods}

For data collection, a DGPS Hemisphere R130 position with sub-metric position accuracy and differential correction via $\mathrm{L}$-band (communication satellite) was used. The survey vessel was an aluminum boat with outboard motor with a maximum draft of $50 \mathrm{~cm}$, so that we could climb the whole low course of the river.

For navigation and storage of the positioning data, a Notebook was used with the Hypack 2012 software to which the DGPS positioner was connected and navigated over georeferenced Google Earth image in Oasis Montaj 8.4 software. The positioning data was stored in digital files.

The survey lines were carried out between the vicinity of the mouth and the area of boulders located at the end of the coastal plain. The lines followed the course of the river (Fig. 4), rising and falling that course, in order to cover the largest possible area of the fluvial bottom, considering the restrictions imposed by the hull of the boat.

The side-scan sonar, a Tritech Starfish 452, small, lightweight, low-cost, but excellent imaging equipment, was mounted on the side of the vessel through a tubular support. The physical characteristics of tow fish size and weight allow the operation of the equipment attached to the vessel's edge rather than towed by the electromechanical communication cable between transducer and control-unit. The sonar and DGPS were connected to another notebook where Scanline of Tritech software was installed to control and store sonar data.

Subsequently, in the Laboratório de Oceanografia Geológica (LABOGEO; Geological Oceanography Laboratory) of the Faculdade de Oceanografia of Universidade do Estado do Rio de Janeiro, UERJ, sonar data were copied to a high-performance computer where Sonarwiz 5 software was installed for sonar data processing. The sonar lines were imported to Sonarwiz 5, making some adjustments of brightness and contrast to improve the images for visualization of the background textures and background features.
Then the observed features and textures were delimited, generating location points and georeferenced polygons. The polygons created to delimit features and textures were exported as Arc Gis Shape Files and imported into Geosoft Oasis Montaj 8.4, where the cartographic base had already been made. From the "shape file", each feature/ texture was identified through a colored polygon and, when applicable, its area was calculated.

\section{Results and Discussion}

Starting from upstream, the two first observed features are a rock slab and a field of boulders (Fig. 5). These features are at the junction of the Rocky Channels sector of the river with the Meandering River Channels with Fine Sediments described by Oliveira et al. (2014), at the entrance of the watercourse in the coastal plain.

The rock slab is an outcropping of the local crystalline basement while the boulders are resulted of the mass movements of the slopes and floods, which promoted the displacement of large rock blocks and fine matrix. Over time, the fine matrix is remobilized and the blocks remain, generating the field of boulders.

Next, the beginning of the sedimentary bottom of the river can be observed as well as the margin bank, delimited by the purple polygon, in several stretches along the entire fluvial extension in the local coastal plain (Fig. 6). This section characterizes the region of the river described as proximal by Gama et al. (2009) or Meandering River Channels with Fine Sediments by Oliveira et al. (2014), where the river channel is semi-confined with floodplain during flood events. The mapped ravines impose a semiconfinement to the fluvial flow in its normal regime.

Continuing the descent way, the landing ramp of the CEADS was observed. The concrete ramp and the tires used as defense to protect the hulls of the boats that are anchored there, can be seen in Fig. 7. These two features were the only mapped evidence of anthropogenic intervention in the Barra Grande River bottom.

Further down, the mangrove roots are detected on the right margin of the river. They are recorded in the sonogram as an irregular pattern of response, similar to a tangle of cables or wires (Fig. 8). The mangrove presence attests the influence of the tidal prism which introduces seawater into the system, which is essential for the development of this kind of forest. 


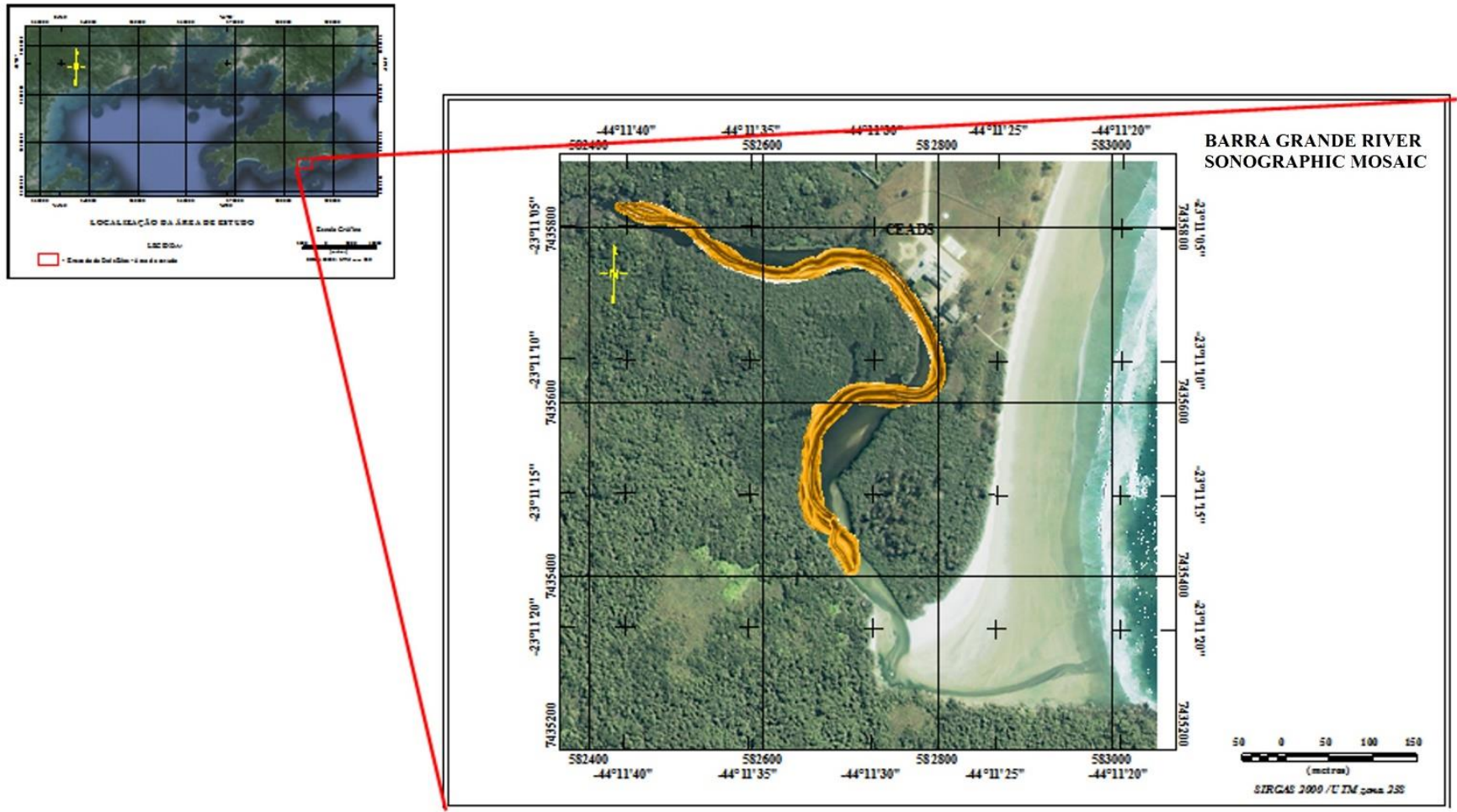

Fig. 4. - Map of the lower course of the Barra Grande River showing the mosaic of the collected sonar images. CEADS - Center for Environmental Studies and Sustainable Development of Ilha Grande.

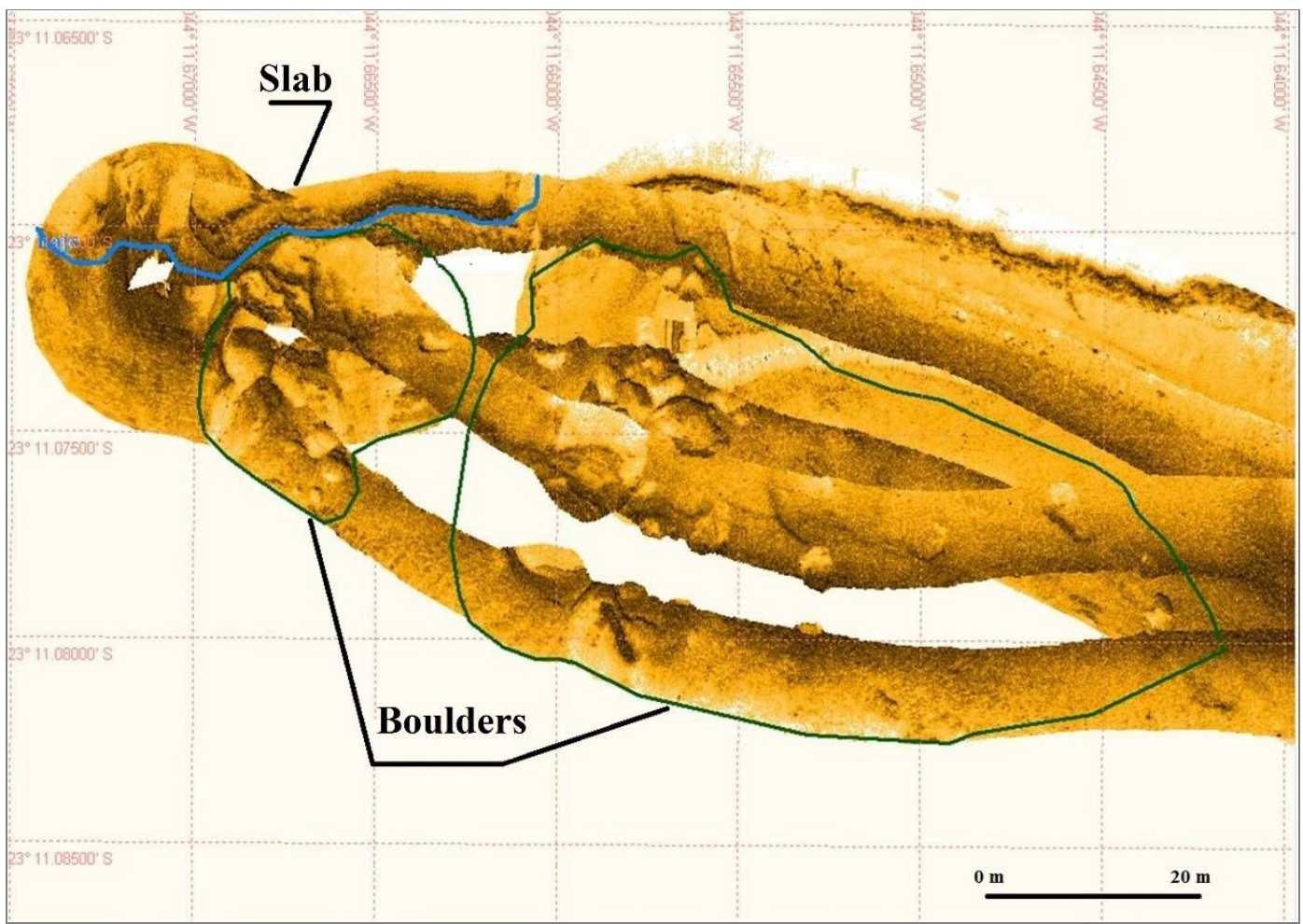

Fig. 5. - Sonar image upstream, at the beginning of the coastal plain of Dois Rios, showing the rocky slab delimited in blue and the field of abutments delimited in green. 


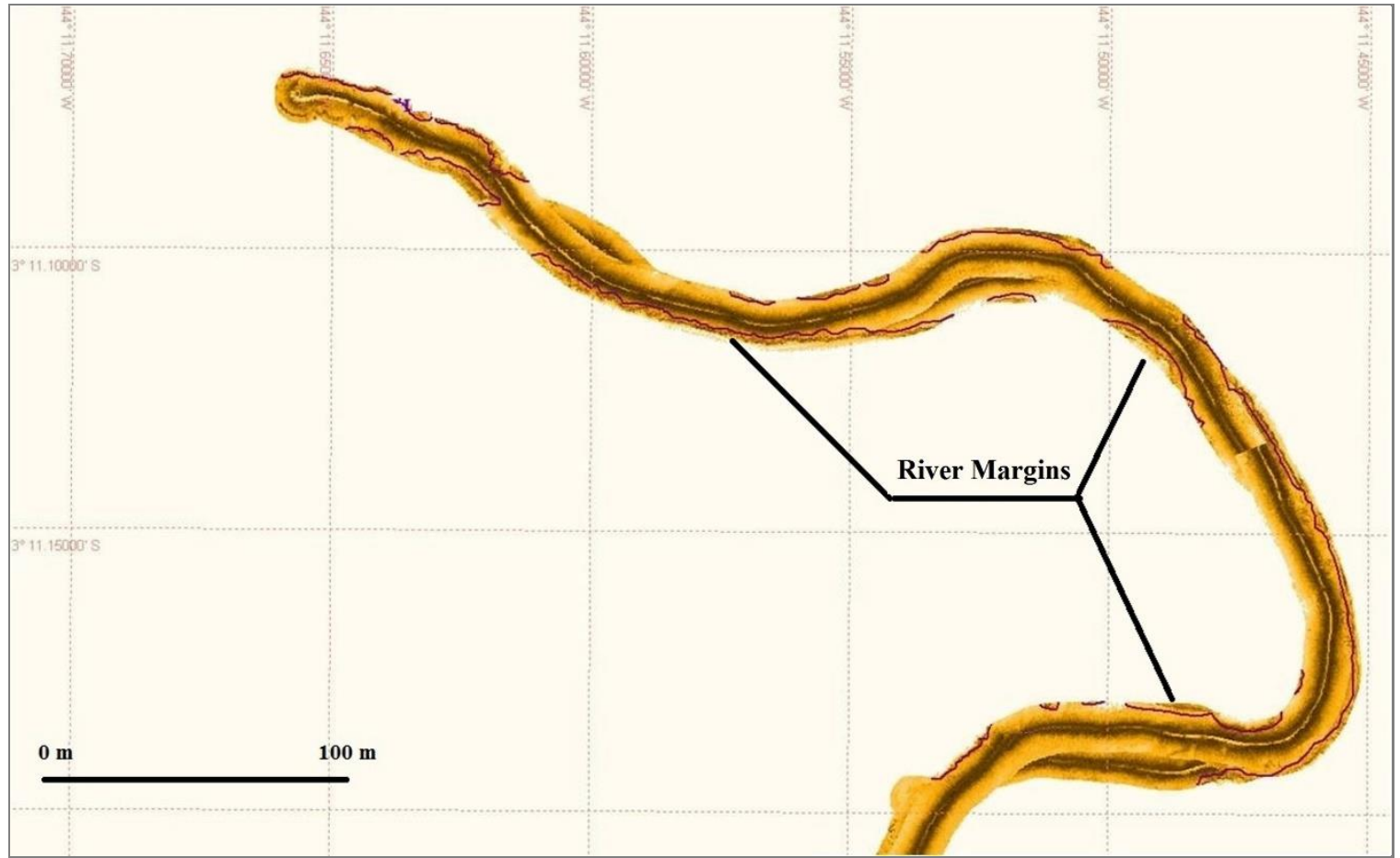

Fig.6. - Mosaic of all sonar imaging of the Barra Grande River with the delimitation of the margin bank in purple.

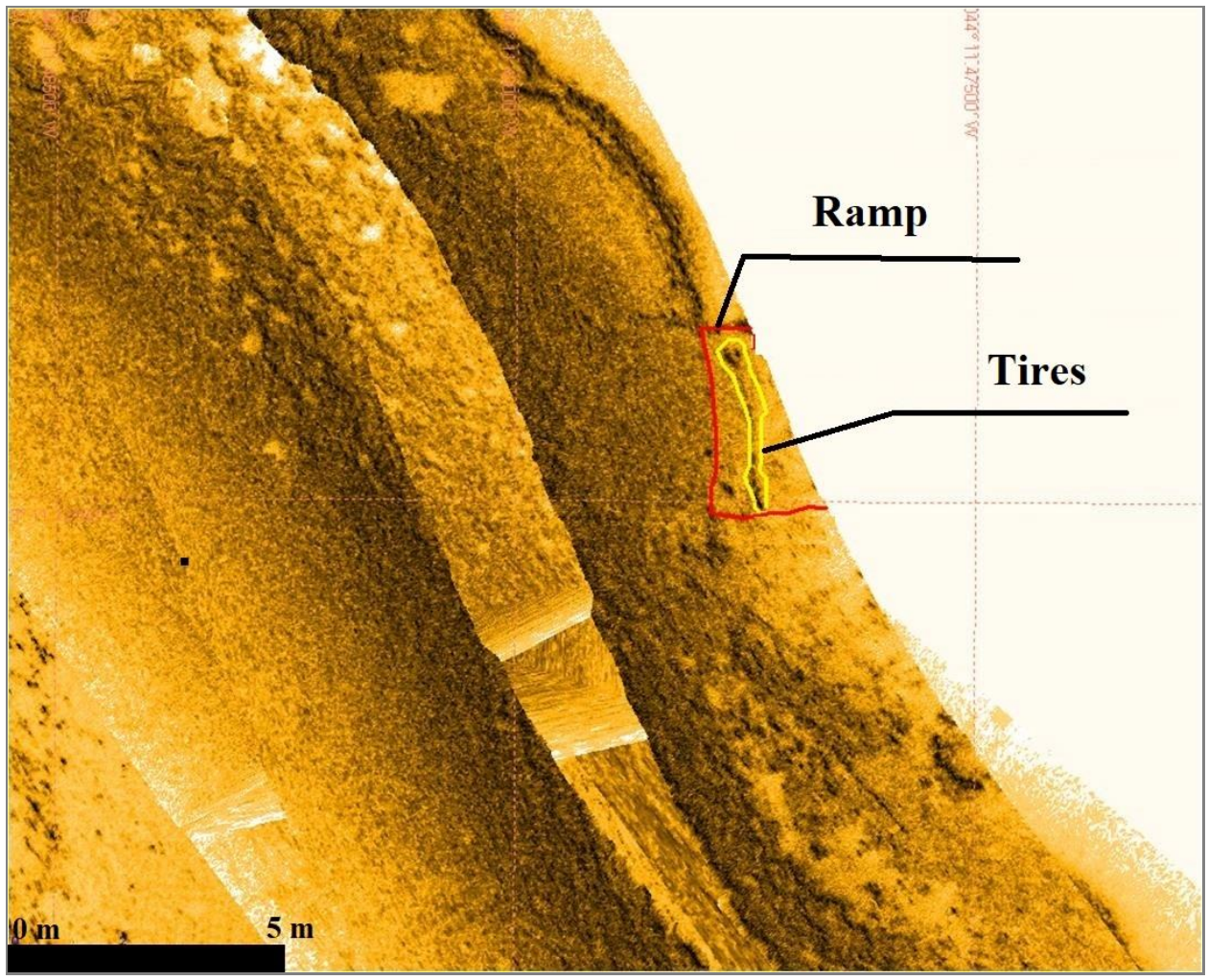

Fig. 7. Detail of the sonar image in the area of the landing ramp of the CEADS - Center for Environmental Studies and Sustainable Development of Ilha Grande, bounded the concrete structure in red and the yellow defense tires. 


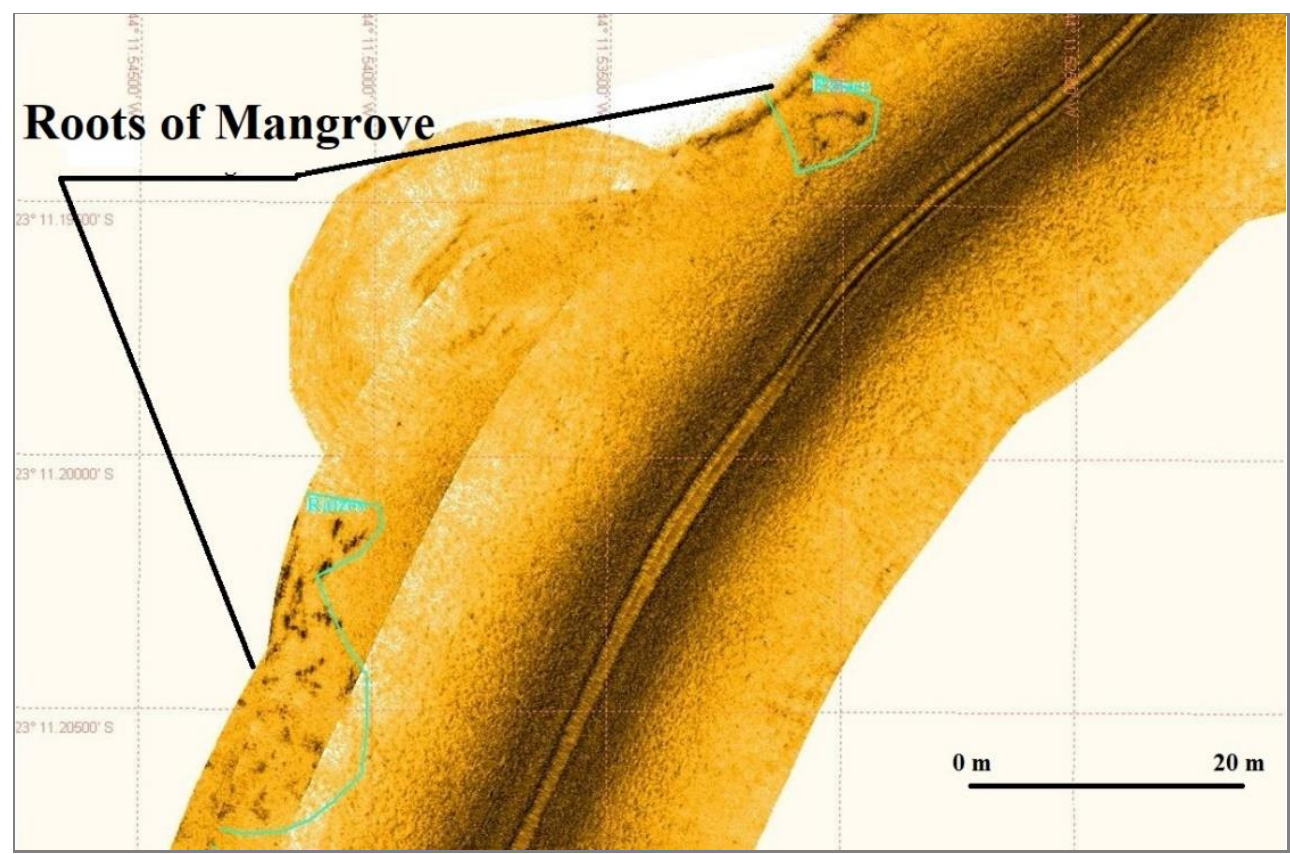

Fig. 8. - Sonogram detail showing the structures identified as mangrove roots delimited in light green and probably associated with mass movement (material slides) of higher dimensions.

A little further down, the final portion of the sonographic survey was reached, in the area where the tide has a great influence on sediment transport and deposition. On the right margin of this region, the roots of the mangrove and a field of bushes can be observed, and sandbanks were found on the left margin (Figs. 9, 10). This distribution is explained by the location of these features, in a meander of the river, near the mouth. The roots are located on the outer face of the curve, where erosive processes predominate, exposing the roots more easily, while the sandbank is located on the inner face of the meander, where there is typically a reduction of fluvial flow and deposition of the transported sediments (sand in this case).

Tidal currents transport sand from the beach to the interior of the estuarine area. The boulders are found on the right margin and are the features closest to the river mouth. They are near the slope and are probably the result of mass movements (sliding material) of greater dimensions. The sandbanks, as well as the beach adjacent to the river mouth (Fig. 10), have materials (namely heavy minerals) provided by the crystalline basement, composed of granites and charnockites with a localized presence of diabase dikes, which is cut by the river. The action of the waves and tides rework the sediment and concentrates the heavy minerals in localized spots.
The areas of the most important features were for the: Boulders Fields $\approx 936 \mathrm{~m}^{2}$; sandbanks $\approx 2827 \mathrm{~m}^{2}$ and; mangrove roots, $\approx 200 \mathrm{~m}^{2}$. If we consider the entire coastal plain of Dois Rios, these areas can be considered small. But they can be considered significant if only the mapped area of the riverbed is taken into account.

The Barra Grande River final map is shown in Fig. 11, where the the low river course crossing the coastal plain of Dois Rios can be observed. The mapped features are closely related to the geological and geomorphological domains described by Gama et al. (2009) and Oliveira et al. (2014).

The banks of boulders are close to the slope in the southern part of the cove and in the transition between the Rocky Channel of the river and the Meandering River Channels with Fine Sediments (Fig. 11).

The mangrove and the tidal floodplain on the right river bank is observed, while on the left, the ravine margin dominates making semi-confined the fluvial course (Fig. 11). The presence of the sandbanks is observed in the portion where tidal currents acts, transporting and depositing sandy sediments (Fig. 11).

The landing ramp of the CEADS and the tire protection are the only anthropic constructions located on the final course of the river coastal plain (Fig. 11). 


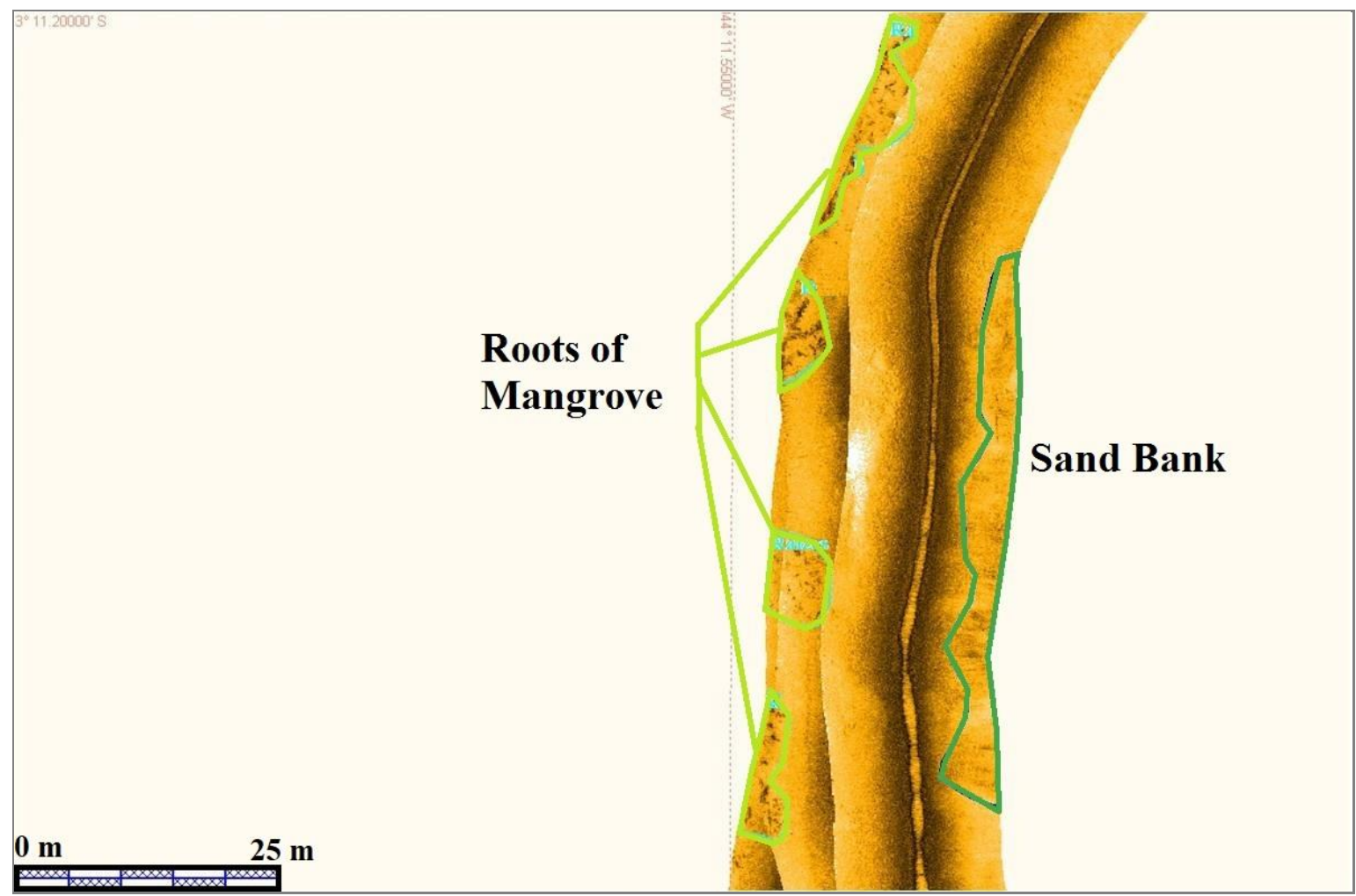

Fig. 9. Detail of sonographic image with identification of mangrove roots (light blue) and sandy bank (Dark blue).

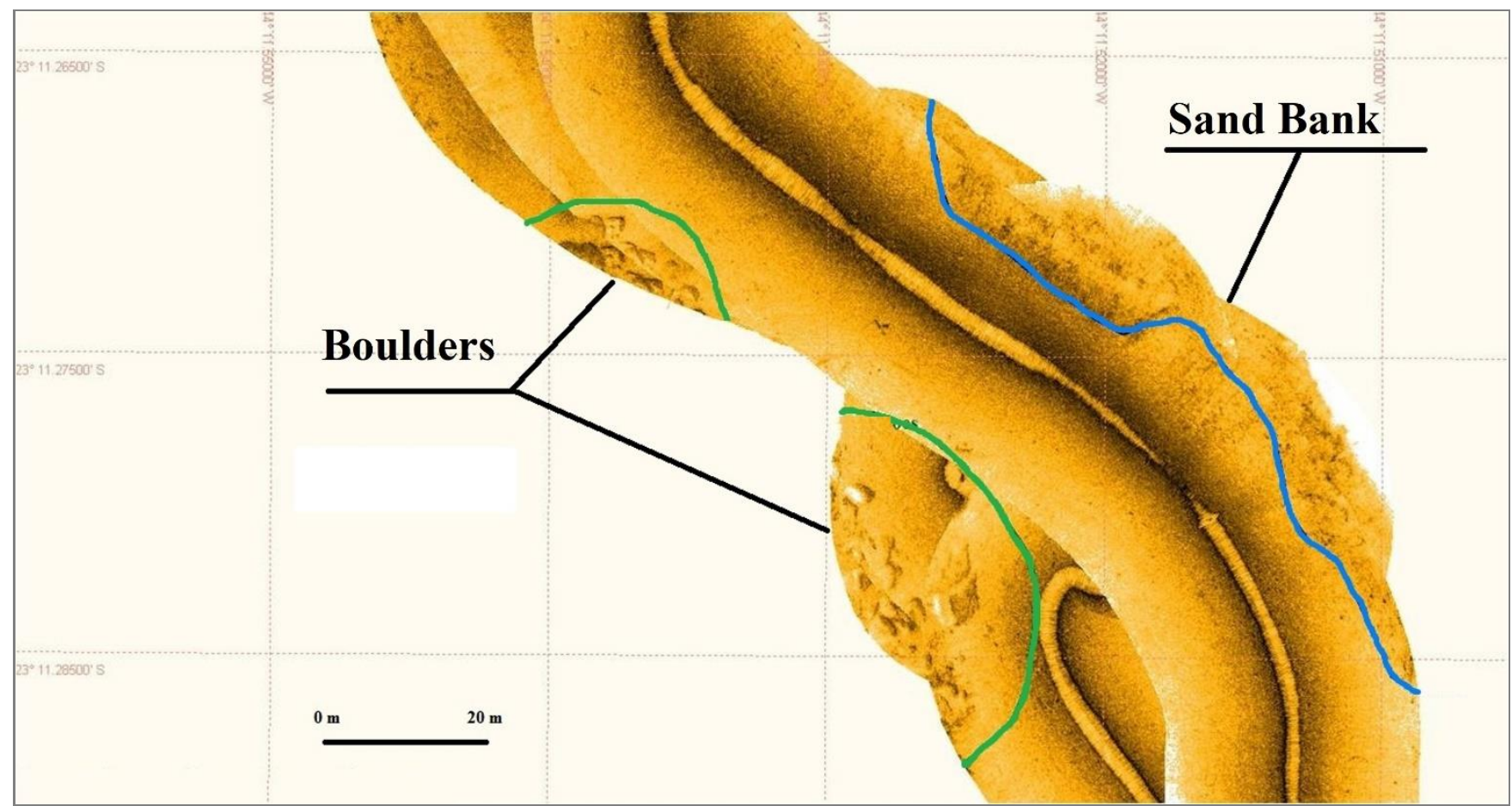

Fig. 10. Detail of the sonographic image with the identification of the second sandbank and the second bank of boulders. 


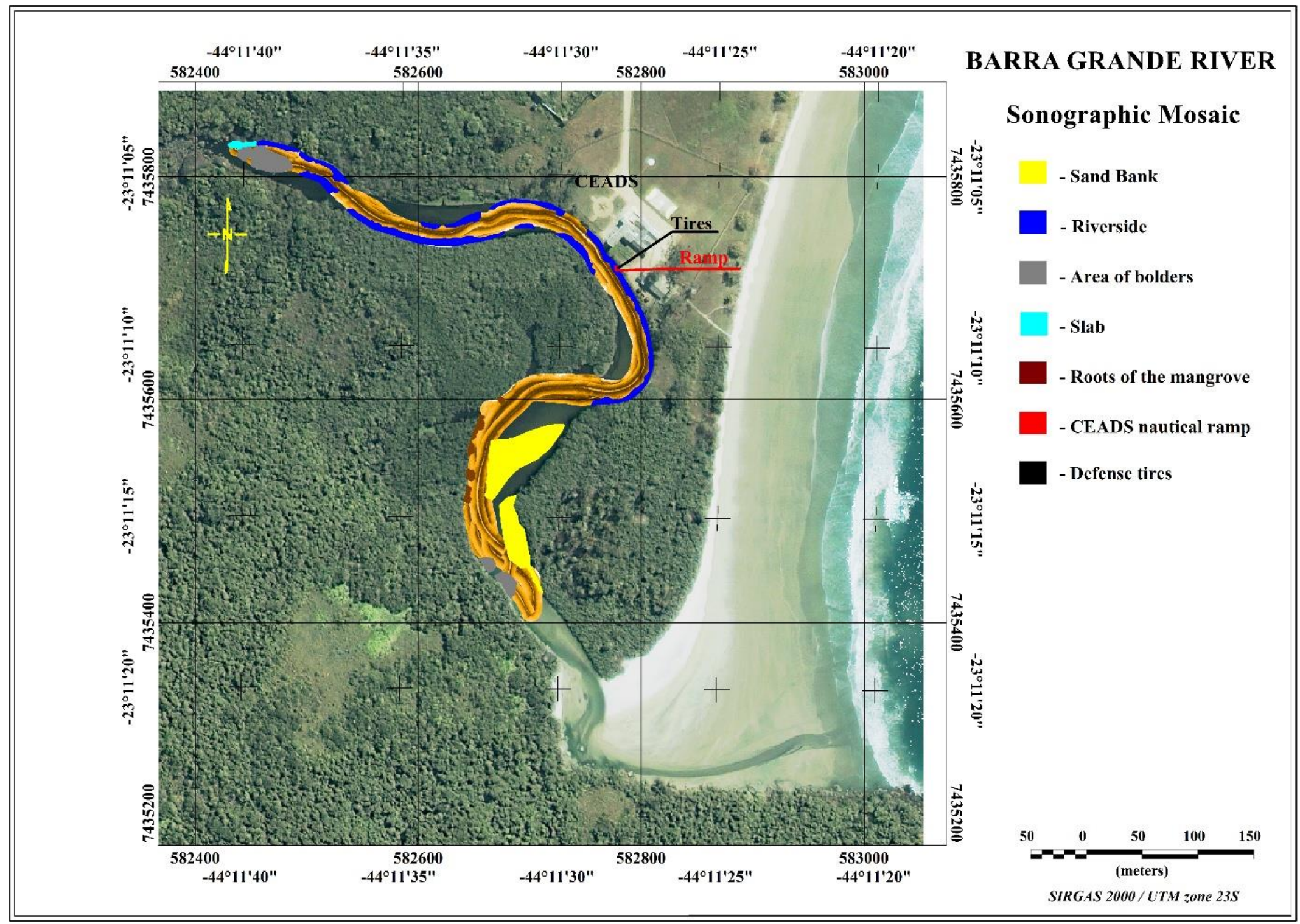

Fig. 11. - Sonographic Map of the Barra Grande River, with the identification of individualized features / targets. 


\section{Conclusion}

The present work evidences the effectiveness of the small lateral scanning sonar in mapping ultra-shallow areas. This equipment allowed to obtain images of excellent quality which enabled the identification of patterns and features of interest in the bottom of the Barra Grande River.

The features and the mapped patterns are clearly related to the geomorphological domains and proximal and distal zones of the river described in the literature. Some features are observed, such as: areas of landslides associated to places subject to mass movements; a rocky slab in an area close to a slope, denoting the outcrop of the rocky basement; the mangroves located where the margin of the river is low and allows the marine water flood in high tides, namely in spring tide. The "ravine" that delimits the channel and determines the confinement in periods of river drought, described in the literature. The sandbanks with the presence of heavy minerals supplied by the basement rocks are in the river portion where tidal currents transport and deposit the reworked sandy sediments. The anthropic action in the river is reduced, and was observed only in the dependencies of the CEADS, where there is a ramp for embarkation and disembarkation.

\section{Acknowledgment}

The authors would like to thank the Carlos Chagas Foundation (CnPQ) for research financial support, which enabled the acquisition of the sonar by the Faculdade de Oceanografia of UERJ and the collection of data; to CEADS, which provided all the support of food, lodging and land and nautical transport to carry out this study.

\section{References}

CPRM, 2007. Mapa Geológico: Folha Angra dos Reis SF23-Z-CII.

Fortes, J.D.N., Pereira, C.Q., 2009. Hidrografia e hidrologia. In: Bastos, M., Callado, C.H. (orgs.), O Ambiente da Ilha Grande, UERJ/CEADS, Rio de Janeiro, pp. 21-64.

Gama, S.V.G., Silva, L.G.A.E., Salgado, C.M., 2009. Geologia, relevo e solos. In: Bastos, M., Callado, C.H. (orgs.), O Ambiente da Ilha Grande, UERJ/CEADS, Rio de Janeiro, pp. 21-64.

Heilbron, M., Pedrosa-Soares, A.C., Campos Neto, M., Silva, L.C., Trouw, R.A.J., Janasi, V. 2004. A Província Mantiqueira. In: V.
Mantesso Neto, Bartorelli, C.D.R., Carneiro, B.B. Brito Neves (orgs), Geologia do Continente Suylamericano: Evolução da Obra de Fernando Flávio Marques de Almeida, São Paulo, Beca, p 203-234. http://www.geologia.ufc.br/wpcontent/uploads/2016/02/geologia-do-continente.pdf

Janela, M., 2014. Ahmed Gabr breaks record for deepest SCUBA dive at more than 1,000 feet. Guinness World Records. http://www.guinnessworldrecords.com/news/2014/9/ahme d-gabr-breaks-record-for-deepest-scuba-dive-at-more-than1000-feet-60537\#

Kaiser, M.J., Atrill, M.J. Jennings, S. Thomas, D.N., Barnes, D.K.A., 2011. Marine Ecology: Process, Systems, and Impacts. Second Edition. Oxford university Press.

Lurton, X., 2002. Development of Underwater Acoustics. In: A Introduction to underwater Acoustics: Principles and Applications. Springer-Praxis.

Mahiques, M.M, Furtado, V.V., Tessler, M.G. 1989. Origin and evolution of isolated depressions on the coastal region of São Paulo and Rio de Janeiro States. In: International Symposium on Global Changes In South America During the Quaternary, 1989. São Paulo, SP. p. 285-288.

Oliveira, B.R.G., Silva, T.M., Rosso, T.C.A, 2014. Estilos fluviais nas bacias hidrográficas da Vila Dois Rios, Ilha Grande (RJ). Revista Geonorte, Edição Especial 4, 10 (1), 281-285.

SEMADS, Secretaria de Estado de Meio Ambiente e Desenvolvimento Sustentável, 2001. Bacias hidrográficas e rios fluminenses: síntese informativa por macrorregião ambiental. Rio de Janeiro. 73 p.

Telford, W.M., Geldart, L.P., Sheriff, R.E. 1990a. Gravity Methods. In: Applied Geophysics, $2^{\text {nd }}$ ed., Cambridge University Press, p. $6-61$.

Telford, W.M., Geldart, L.P., Sheriff, R.E. 1990b. Magnetic Methods. In: Applied Geophysics, 2 ${ }^{\text {nd }}$ ed., Cambridge University Press, p. 62 - 135.

Torres, L.C., Villena, H.H., Rangel, A.A. 2010. Norte Brasileira Ridge System, an example of natural component or natural prolongation of the Brazilian Continental Margin? 6th IHOIAG ABLOS Conference International Hydrographic Bureau, Monaco, At Monte Carlo - Monaco. https://www.iho.int/mtg_docs/com_wg/ABLOS/ABLOS_ Conf6/S9P2-P.pdf

Valeriano, C.M., Mendes, J.C., Tupinambá, M., Bongiolo, E., Heilbron, M. Junho, M.C.B. 2016. Cambro-Ordovician postcollisional granites of the Ribeira belt, SE-Brazil: A case of terminal magmatism of a hot orogeny. Journal of South American Earth Sciences, 68, 269-281. https://doi.org/10.1016/j.jsames.2015.12.014 